\title{
Increased expression of EGR1 and KLF4 by polysulfide via activation of the ERK1/2 and ERK5 pathways in cultured intestinal epithelial cells
}

\author{
Kaoru Arakaki ${ }^{1,2}$, Ayako Uehara ${ }^{1,2}$, Sayomi Higa-Nakamine ${ }^{1}$, Manabu Kakinohana ${ }^{2}$, and Hideyuki Yamamoto ${ }^{1}$ \\ ${ }^{1}$ Departments of Biochemistry, and ${ }^{2}$ Anesthesiology, Graduate School of Medicine, University of the Ryukyus, Okinawa 903-0215, Japan \\ (Received 31 January 2020; and accepted 19 February 2020)
}

\begin{abstract}
Sodium trisulfide $\left(\mathrm{Na}_{2} \mathrm{~S}_{3}\right)$ releases hydrogen polysulfide $\left(\mathrm{H}_{2} \mathrm{~S}_{\mathrm{n}}\right)$ and is useful for the investigation of the effects of $\mathrm{H}_{2} \mathrm{~S}_{\mathrm{n}}$ on the cell functions. In the present study, we first examined the effects of $\mathrm{Na}_{2} \mathrm{~S}_{3}$ on the gene expression of IEC-6 cells, a rat intestinal epithelial cell line. Microarray analysis and reverse transcription-polymerase chain reaction analysis revealed that $\mathrm{Na}_{2} \mathrm{~S}_{3}$ increased the gene expression of early growth response 1 (EGR1) and Kruppel-like transcription factor 4 (KLF4). It was interesting that U0126, an inhibitor of the activation of extracellular signal-regulated kinase 1 (ERK1), ERK2, and ERK5, inhibited the $\mathrm{Na}_{2} \mathrm{~S}_{3}$-induced gene expression of EGR1 and KLF4. $\mathrm{Na}_{2} \mathrm{~S}_{3}$ activated ERK1 and ERK2 (ERK1/2) within 15 min. In addition to ERK1/2, $\mathrm{Na}_{2} \mathrm{~S}_{3}$ activated ERK5. We noticed that the electrophoretic mobility of ERK5 was decreased after $\mathrm{Na}_{2} \mathrm{~S}_{3}$ treatment. Phos-tag analysis and in vitro dephosphorylation of the cell extracts indicated that the gel-shift of ERK5 was due to its phosphorylation. The gel-shift of ERK5 was inhibited completely by both U0126 and ERK5-IN-1, a specific inhibitor of ERK5. From these results, we concluded that the gel-shift of ERK5 was induced through autophosphorylation by activated ERK5 after $\mathrm{Na}_{2} \mathrm{~S}_{3}$ treatment. The present study suggested that $\mathrm{H}_{2} \mathrm{~S}_{\mathrm{n}}$ affected various functions of intestinal epithelial cells through the activation of the ERK1/2 and ERK5 pathways.
\end{abstract}

\section{INTRODUCTION}

Hydrogen sulfide $\left(\mathrm{H}_{2} \mathrm{~S}\right)$ is an environmental hazard produced by natural sources. High levels of $\mathrm{H}_{2} \mathrm{~S}$ are cytotoxic primarily due to the inhibition of mitochondrial cytochrome $\mathrm{C}$ oxidase (for review, see Kakinohana et al. 2019). In contrast, $\mathrm{H}_{2} \mathrm{~S}$ has been identified as the third gaseous transmitter, following nitric oxide and carbon monoxide (Guo et al. 2016). It has been reported that $\mathrm{H}_{2} \mathrm{~S}$ has various biological effects in the nervous system, the cardiovascular system, and the immune system (Guo et al. 2016; Kimura 2017). There are accumulating data that $\mathrm{H}_{2} \mathrm{~S}$

Address correspondence to: Hideyuki Yamamoto, Department of Biochemistry, Graduate School of Medicine, University of the Ryukyus, 207 Uehara, Nishihara, Okinawa 903-0215, Japan

Tel: +81-98-895-1114, Fax: +81-98-895-1404

E-mail: hideyuki@med.u-ryukyu.ac.jp has neuroprotective effects in the central nervous system (Hu et al. 2009; Xie et al. 2015). Recently, we found that breathing of $\mathrm{H}_{2} \mathrm{~S}$ prevented delayed paraplegia after spinal cord ischemia in mice (Kakinohana et al. 2019). These results suggested that $\mathrm{H}_{2} \mathrm{~S}$ had anti-apoptotic effects on spinal neurons.

There are three enzymes involved in the endogenous production of $\mathrm{H}_{2} \mathrm{~S}$ : cystathionine $\beta$-synthetase (CBS), cystathionine $\gamma$-lyase (CSE), and 3-mercaptopyruvate sulfurtransferase. Among these enzymes, CBS and CSE are expressed in the intestinal epithelial cells (Hosoki et al. 1997; Blachier et al. 2019). In addition to endogenous production by the enzymes in the intestinal epithelial cells, $\mathrm{H}_{2} \mathrm{~S}$ is produced also by the intestinal microbiota (Blachier et al. 2019). It was reported that the concentration of $\mathrm{H}_{2} \mathrm{~S}$ ranged from $0.2 \mathrm{mM}$ to $1 \mathrm{mM}$ in mouse stools (Rose et al. 2005). These reports indicate that intestinal epithelial cells are exposed to the higher concentration of $\mathrm{H}_{2} \mathrm{~S}$ than any other cells in other 
organs. There are many reports that $\mathrm{H}_{2} \mathrm{~S}$ is involved in the pathophysiological conditions of inflammatory bowel diseases (IBD), such as ulcerative colitis and Crohn's disease, and colorectal cancer (Wallace et al. 2007; Rowan et al. 2009; Hirata et al. 2011; Guo et al. 2016). However, the physiological and pathophysiological roles of $\mathrm{H}_{2} \mathrm{~S}$ in the intestinal epithelium remain to be elucidated.

It is known that $\mathrm{H}_{2} \mathrm{~S}$ is converted to hydrogen polysulfides $\left(\mathrm{H}_{2} \mathrm{~S}_{\mathrm{n}}, \mathrm{n} \geqq 2\right)$ and then $\mathrm{H}_{2} \mathrm{~S}_{\mathrm{n}}$ affect various cell functions (Kimura 2017). $\mathrm{H}_{2} \mathrm{~S}_{\mathrm{n}}$ have been reported to regulate the activities of ion channels and protein kinases (for review, see Miyamoto et al. 2017). It is highly possible that intestinal epithelial cells are exposed to the high concentrations of $\mathrm{H}_{2} \mathrm{~S}_{\mathrm{n}}$ that are converted from $\mathrm{H}_{2} \mathrm{~S}$, but the effects of $\mathrm{H}_{2} \mathrm{~S}_{\mathrm{n}}$ on intestinal epithelium are not clear at present.

IEC-6 cells are immortalized rat intestinal epithelial cells. We have been studying about various mitogen-activated protein kinase (MAPK) pathways in IEC-6 cells. Among the MAPK pathways, the p38 MAPK pathway was activated by the stimulation of toll-like receptor 5 (TLR5) to enhance the cell migration (Kondo et al. 2016). In the present study, we sought to examine the effects of $\mathrm{H}_{2} \mathrm{~S}_{\mathrm{n}}$ on the MAPK pathways and cell functions of IEC-6 cells. Sodium trisulfide $\left(\mathrm{Na}_{2} \mathrm{~S}_{3}\right)$ is useful for investigation of the effects of $\mathrm{H}_{2} \mathrm{~S}_{\mathrm{n}}$ on cell functions. Therefore, we treated IEC-6 cells with $\mathrm{Na}_{2} \mathrm{~S}_{3}$, and we first examined the effects of the gene expression by microarray analysis. We found that the mRNAs of early growth response 1 (EGR1) and Kruppel-like transcription factor 4 (KLF4) were increased by $\mathrm{Na}_{2} \mathrm{~S}_{3}$. Interestingly, the increases in the mRNAs of EGR1 and KLF4 were completely inhibited by an inhibitor of the activation of extracellular signal-regulated kinase (ERK1), ERK2 and ERK5. We then confirmed that $\mathrm{Na}_{2} \mathrm{~S}_{3}$ activated ERK1, ERK2, and ERK5. In addition, the molecular mechanisms for the gel-shift of ERK5 after $\mathrm{Na}_{2} \mathrm{~S}_{3}$ treatment were examined.

\section{MATERIALS AND METHODS}

Materials. The following chemicals and reagents were obtained from the indicated sources: Dulbecco's modified Eagle's medium (DMEM) and phosphate-buffered saline from Sigma Chemical Co. (St. Louis, MO, USA); fetal calf serum (FCS) from HyClone (Logan, UT, USA). DynaMarker Protein MultiColor, BioDynamics Laboratory Inc. (Tokyo, Japan); U0126 (9903), anti-ERK5 antibody, anti-JNK antibody, anti-p38 MAPK antibody, anti-phospho-ERK5 antibody, anti-phospho-JNK antibody, and anti-phos- pho-p38 MAPK antibody from Cell Signaling Technology (Beverly, MA, USA); anti-ERK1/2 antibody, Sigma Chemical Co. (St Louis, MO, USA); anti-active ERK1/2 antibody, Promega Co. (Madison, WI, USA); BAY 43-9006, Cayman Chemical (Ann Arbor, MI, USA); ERK5-IN-1, Selleck Chemicals (Houston, TX, USA); and protease inhibitor cocktail, Nacalai Tesque (Kyoto, Japan). Other chemicals were of analytical grade.

Cell culture and $\mathrm{Na}_{2} \mathrm{~S}_{3}$ treatment. IEC-6 cells were obtained from the American Tissue Culture Collection (Manassas, VA, USA). The cells were grown in Petri dishes (Nunc, Roskilde, Denmark) in DMEM containing $4.5 \mathrm{~g} / \mathrm{L}$ glucose and $10 \%$ (vol/vol) heatinactivated FCS. Before the cell treatment, the medium was exchanged to DMEM containing $0.1 \%$ FCS, and the cells were cultured for $2 \mathrm{~h}$. We stored $\mathrm{Na}_{2} \mathrm{~S}_{3}$ at $4{ }^{\circ} \mathrm{C}$, and opened the cap after reaching room temperature. Just before the treatment of the cells, we prepared $100 \mathrm{mM} \mathrm{Na}_{2} \mathrm{~S}_{3}$ solution with $\mathrm{H}_{2} \mathrm{O}$ purged with $\mathrm{N}_{2}$ gas. The cells were then treated with $\mathrm{Na}_{2} \mathrm{~S}_{3}$ for the indicated time intervals.

Microarray analysis and reverse transcription-polymerase chain reaction. After treatment of IEC-6 cells with $100 \mu \mathrm{M} \mathrm{Na}_{2} \mathrm{~S}_{3}$ for $60 \mathrm{~min}$, total RNA was extracted using an RNeasy Mini Kit (Qiagen, Gaithersburg, MD, USA) in accordance with the manufacturer's directions, and the amount of total RNA was determined by measuring absorbance at $260 \mathrm{~nm}$ using a Nano Drop 2000 spectrophotometer (Thermo Fisher Scientific, MA, USA). The expression profile of mRNA was determined using a SurePrint G3 Rat GE Microarray $(8 \times 60 \mathrm{~K}$ v2) (Agilent Technology, Santa Clara, CA, USA). The experiment was performed by Cell Innovator Inc. (Fukuoka, Japan). The genes for which the $\mathrm{Z}$ score and the ratio were above 2.0 and 1.5 , respectively, were considered up-regulated. In contrast, the genes for which the $\mathrm{Z}$ score and the ratio were below -2.0 and 0.66 , respectively, were considered down-regulated. All microarray data were MIAME compliant, and the raw data have been deposited in the Gene Expression Omnibus (GEO) database, with the accession number GSE139672.

For reverse transcription-polymerase chain reaction (RT-PCR), first-strand cDNA was synthesized from $2 \mu \mathrm{g}$ of total RNA in a $20 \mu \mathrm{L}$ reaction volume using AMV Reverse Transcriptase (Promega Co.) with an Oligo dT-Adaptor primer. For the amplification of EGR1, we used as a sense primer, CGCTCA CTCCACTATCCACT, and as an antisense primer, 
ACTCAACAGGGCAAGCATAC. For the amplification of FOS, we used as a sense primer, CAAGCC GACACAGATCAACT, and as an antisense primer, AGACATCTCCTCTGGGAAGC. For the amplification of Kruppel-like transcription factor 4 (KLF4), we used as a sense primer, GCCCCAAGATTAAGG AAGAG, and as an antisense primer, TTCCTCGGG ACTCAGTGTAG. For the amplification of glyceraldehyde-3-phosphate dehydrogenase (GAPDH), we used as a sense primer, ACCACAGTCCATGCCAT $\mathrm{CAC}$, and as an antisense primer, TCCACCACC CTGTTGCTGTA. Preliminary PCR experiments were performed to identify the linear amplification conditions for each product. Amplification of EGR1, FOS, KLF4, and GAPDH was performed for 25, 28, 25 , and 22 cycles $\left(30 \mathrm{~s}\right.$ at $94^{\circ} \mathrm{C}, 1 \mathrm{~min}$ at $58^{\circ} \mathrm{C}, 1 \mathrm{~min}$ at $70^{\circ} \mathrm{C}$ ), respectively, with Expand Long-Range dNTPack (Roche Diagnosis, Indianapolis, IN, USA). The PCR products were separated by electrophoresis in a $1.5 \%$ agarose gel, visualized by ethidium bromide staining, and quantified using an ImageQuant LAS 4000 mini (GE Healthcare UK Ltd.) with Multi Gauge software (version 3.1).

Preparation of cell extract. For the preparation of cell extracts, IEC-6 cells in 60-mm Petri dishes (Nunc) were washed once in phosphate-buffered saline and lysed in $300 \mu \mathrm{L}$ of $1 \times$ SDS-PAGE sample buffer containing $2 \%(\mathrm{wt} / \mathrm{vol})$ SDS, $62.5 \mathrm{mM}$ Tris$\mathrm{HCl}, \mathrm{pH} 6.8,5 \%$ (vol/vol) 2-mercaptoethanol, 5\% (vol/vol) glycerol, and $0.01 \%$ (wt/vol) bromophenol blue (Laemmli 1970). The cell extract was sonicated for $20 \mathrm{~s}$ on ice, heated at $98^{\circ} \mathrm{C}$ for $5 \mathrm{~min}$, and kept at $-80^{\circ} \mathrm{C}$ until use (Higa-Nakamine et al. 2012).

SDS-PAGE, Phos-Tag SDS-PAGE, and immunoblotting analysis. SDS-PAGE was performed using the method of Laemmli (1970) followed by immunoblotting analysis (Towbin et al. 1979; Mizutani et al. 2011). In the case of Phos-Tag SDS-PAGE, we used precast $7.5 \%(\mathrm{wt} / \mathrm{vol})$ acrylamide gels that contained $50 \mu \mathrm{M}$ Phos-Tag and formed a Zinc complex (Code No. 195-17371; Fujifilm Wako Pure Chemical Co., Osaka, Japan). Immunoreactive proteins were detected using an enhanced chemiluminescence detection kit (GE Healthcare UK Ltd., Little Chalfont, UK) and an ImageQuant LAS 4000 mini (GE Healthcare UK Ltd.) with Image Reader LAS 4000 mini (version 1.0; GE Healthcare UK Ltd.) in accordance with the manufacturer's instructions. The level of immunoreactivity was quantified using Multi Gauge software (version 3.1). For reprobing, the membrane was incubated with stripping buffer con- taining $62.5 \mathrm{mM}$ Tris- $\mathrm{HCl}$, pH 6.7, $100 \mathrm{mM}$ 2-mercaptoethanol, and $2 \%(\mathrm{wt} / \mathrm{vol}) \mathrm{SDS}$ at $50^{\circ} \mathrm{C}$ for 30 min (Noguchi et al. 2013). The membrane was then washed with a blocking solution containing 5\% (wt/vol) skim milk, $100 \mathrm{mM}$ Tris-HCl, $\mathrm{pH} 7.5,0.9 \%$ (wt/vol) $\mathrm{NaCl}$, and $0.1 \%$ (vol/vol) Tween-20 followed by Tris-buffered saline with Tween-20 containing $100 \mathrm{mM}$ Tris- $\mathrm{HCl}, \mathrm{pH} 7.5,0.9 \%$ (wt/vol) $\mathrm{NaCl}$, and $0.1 \%$ (vol/vol) Tween-20 at room temperature, and subjected to immunoblotting analysis. For the quantification of the levels of the gel-shift of ERK5, the ratio of the signal of the shifted band to that of the total ERK5 was determined. The experiments were repeated at least three times, and representative results are shown.

Phosphatase treatment. IEC-6 cells were cultured in 100-mm Petri dishes (Nunc), and treated with $100 \mu \mathrm{M} \mathrm{Na} \mathrm{S}_{3}$ for $30 \mathrm{~min}$. The cells were immediately frozen with liquid $\mathrm{N}_{2}$ and lysed in the presence of $150 \mu \mathrm{L}$ of cell lysis buffer containing $10 \mathrm{mM}$ Tris$\mathrm{HCl}, \mathrm{pH} 7.5,1 \mathrm{mM}$ EDTA, $1 \mathrm{mM}$ EGTA, 0.05\% (vol/vol) Triton X-100, and protease inhibitor cocktail by sonication for $20 \mathrm{~s}$ on ice. The cell lysate was centrifuged at $13,000 \times g$ at $4^{\circ} \mathrm{C}$ for $10 \mathrm{~min}$ to obtain the cell extract. The cell extract was incubated with $\lambda$-protein phosphatase (New England Biolabs Inc., Ipswich, MA, USA) in the presence of $1 \mathrm{mM} \mathrm{MnCl}{ }_{2}$ at $30^{\circ} \mathrm{C}$ for $30 \mathrm{~min}$, and then heated at $98^{\circ} \mathrm{C}$ for $5 \mathrm{~min}$ in the presence of $1 \times$ SDS-PAGE sample buffer. The cell extract was kept at $-80^{\circ} \mathrm{C}$, and used for immunoblotting analysis of ERK5 within 3 days.

Other procedures. Protein concentrations were determined using a Qubit Protein Assay Kit with a Qubit 2.0 Fluorometer (Invitrogen, Carlsbad, CA, USA). In pilot experiments, the protein concentration curves were linear in the presence of $0.04 \%$ (wt/vol) SDS, 0.1\% (vol/vol) 2-mercaptoethanol, and $0.1 \%(\mathrm{vol} / \mathrm{vol})$ glycerol. Therefore, we diluted the cell extract 50 -fold with water for protein quantification.

\section{RESULTS}

Microarray analysis after $\mathrm{Na}_{2} \mathrm{~S}_{3}$ treatment

For the first step, we performed microarray analysis to examine the types of genes whose expression was affected by $\mathrm{Na}_{2} \mathrm{~S}_{3}$ in IEC-6 cells. Microarray analysis indicated that 23,480 genes of 45,598 genes examined were expressed in IEC- 6 cells. Among the 23,480 genes, 424 genes and 416 genes were up-reg- 
Table 130 genes that were up-regulated by $\mathrm{Na}_{2} \mathrm{~S}_{3}$

\begin{tabular}{|c|c|c|c|c|}
\hline Number & Gene Symbol & Gene Title & Z score & Ratio \\
\hline 1 & Atf3 & Activating transcription factor 3 & 16.01 & 27.31 \\
\hline 2 & Vegfa & Vascular endothelial growth factor & 12.02 & 9.00 \\
\hline 3 & Trib3 & Tribbles pseudokinase 3 & 11.82 & 23.87 \\
\hline 4 & Fosl1 & Fos-like antigen 1 & 11.49 & 21.83 \\
\hline 5 & Ptgs2 & Cyclo-oxygenase 2 gene & 10.23 & 6.48 \\
\hline 6 & Akr $1 \mathrm{~d} 1$ & Aldo-keto reductase family 1 & 10.17 & 15.31 \\
\hline 7 & Chac1 & ChaC glutathione-specific gamma-glutamylcyclotransferase 1 & 9.89 & 7.72 \\
\hline 8 & Myc & Myelocytomatosis oncogene & 9.41 & 5.59 \\
\hline 9 & Epha2 & Eph receptor A2 & 8.89 & 4.09 \\
\hline 10 & Srxn1 & Sulfiredoxin 1 & 8.86 & 5.05 \\
\hline 11 & Sesn 2 & Sestrin 2 & 8.38 & 9.49 \\
\hline 12 & F3 & Coagulation factor III & 8.25 & 4.51 \\
\hline 13 & $\mathrm{Nppb}$ & Natriuretic peptide B & 8.02 & 4.33 \\
\hline 14 & Vegfa & Vascular endothelial growth factor & 7.13 & 6.79 \\
\hline 15 & Areg & Amphiregulin & 7.10 & 3.08 \\
\hline 16 & Psmb11 & Proteasome & 6.94 & 57.1 \\
\hline 17 & Ddit4 & DNA-damage-inducible transcript 4 & 6.70 & 3.40 \\
\hline 18 & Ddit3 & DNA-damage-inducible transcript 3 & 6.66 & 2.87 \\
\hline 19 & Osgin1 & Oxidative stress induced growth inhibitor 1 & 6.66 & 5.99 \\
\hline 20 & Ifrd1 & Interferon-related developmental regulator 1 & 6.57 & 2.83 \\
\hline 21 & Maff & V-maf avian musculoaponeurotic fibrosarcoma oncogene homolog $\mathrm{F}$ & 6.56 & 3.88 \\
\hline 22 & Slc3a2 & Solute carrier family 3 & 6.48 & 3.27 \\
\hline 23 & Dusp6 & Dual specificity phosphatase 6 & 6.44 & 2.77 \\
\hline 24 & Dusp5 & Dual specificity phosphatase 5 & 6.31 & 5.45 \\
\hline 25 & Egr2 & Early growth response 2 & 6.16 & 3.57 \\
\hline 26 & Mthfd2 & Methylenetetrahydrofolate dehydrogenase & 6.02 & 3.00 \\
\hline 27 & Phlda1 & Pleckstrin homologt-like domain & 6.01 & 5.03 \\
\hline 28 & Klf4 & Kruppel-like transcription factor 4 & 5.93 & 2.56 \\
\hline 29 & Cxcl1 & Chemokinase (C-X-C motif) ligand 1 & 5.82 & 2.89 \\
\hline 30 & Inhbe & Inhibin beta $\mathrm{E}$ & 5.79 & 4.75 \\
\hline 41 & Egr1 & Early growth response 1 & 4.91 & 2.45 \\
\hline
\end{tabular}

ulated and down-regulated, respectively, after $\mathrm{Na}_{2} \mathrm{~S}_{3}$ treatment. Tables 1 and 2 list the 30 genes that were most strongly up-regulated and down-regulated, according to $\mathrm{Z}$ score. We excluded non-coding RNA genes from Tables 1 and 2. Among 30 up-regulated genes, EGR1 and KLF4 were up-regulated 4.9-fold and 5.9-fold, respectively, after $\mathrm{Na}_{2} \mathrm{~S}_{3}$ treatment (Table 1). We performed a pathway enrichment analysis of the 340 up-regulated genes for differentially expressed genes using DAVID database (Huang et al. 2009). Pathway enrichment analysis indicated that 11 genes were related to the MAPK pathways.

\section{RT-PCR of EGR1, KLF4, and FOS mRNAs}

We next examined whether or not $\mathrm{Na}_{2} \mathrm{~S}_{3}$ increased the mRNA levels of EGR1 and KLF4 using RTPCR (Fig. 1). $\mathrm{Na}_{2} \mathrm{~S}_{3}$ treatment increased 2.2-fold and 1.8-fold the mRNA levels of EGR1 and KLF4. Because it has been reported that the gene expression of FOS was increased by the pathway of ERK1 and
ERK2 (ERK1/2), we examined also the change of FOS mRNA level. Unlike the results from microarray analysis, $\mathrm{Na}_{2} \mathrm{~S}_{3}$ treatment increased 2.4-fold the mRNA level of FOS. We further found that U0126, an inhibitor of the activation of ERK1/2, strongly decreased the mRNA levels of EGR1 and FOS regardless of the presence of $\mathrm{Na}_{2} \mathrm{~S}_{3}$. These results suggested that the ERK1/2 pathway was involved in the $\mathrm{Na}_{2} \mathrm{~S}_{3}$-induced gene expression of EGR1 and FOS. Interestingly, the increase in the mRNA level of KLF4 was inhibited also by U0126. It was reported that the gene expression of KLF4 was induced through ERK5 activation in human umbilical vein endothelial cells (Ohnesorge et al. 2010). In addition, it was also shown that U0126 inhibited the activation of ERK5 as well as ERK1/2 (Kamakura et al. 1999). Taken together, we considered the possibility that the ERK5 pathway might be involved in the $\mathrm{Na}_{2} \mathrm{~S}_{3}$-induced gene expression of KLF4. When the mRNA level of GAPDH was examined, no sig- 
Table 230 genes that were down-regulated by $\mathrm{Na}_{2} \mathrm{~S}_{3}$

\begin{tabular}{|c|c|c|c|c|}
\hline Number & GeneSymbol & Gene Title & Z score & Ratio \\
\hline 1 & I16r & Interleukin 6 receptor & -7.28 & 0.01 \\
\hline 2 & Tap2 & Transporter 2 & -7.08 & 0.23 \\
\hline 3 & Ing3 & Inhibitor of growth family, member 3 & -7.03 & 0.23 \\
\hline 4 & Nyap1 & Neuronal tyrosine-phosphorylated phosphoinositide-3-kinase adaptor 1 & -7.03 & 0.01 \\
\hline 5 & Fktn & Fukutin & -6.95 & 0.01 \\
\hline 6 & Fblim1 & Filamin binding LIM protein 1 & -6.89 & 0.01 \\
\hline 7 & LOC257642 & rRNA promoter binding protein & -6.78 & 0.50 \\
\hline 8 & Olr1448 & Olfactory receptor 1448 & -6.55 & 0.02 \\
\hline 9 & Hmg111 & High-mobility group (nonhistone chromosomal) protein 1-like 1 & -6.48 & 0.51 \\
\hline 10 & Bst2 & Bone marrow stromal cell antigen 2 & -6.40 & 0.31 \\
\hline 11 & Olr360 & Olfactory receptor 360 & -6.40 & 0.02 \\
\hline 12 & Ankrd37 & Ankyrin repeat domain 37 & -6.33 & 0.18 \\
\hline 13 & Ptchd1 & Patched domain containing 1 & -6.33 & 0.02 \\
\hline 14 & $\mathrm{Eml2}$ & Echinoderm microtuble associated protein like 2 & -6.27 & 0.27 \\
\hline 15 & Olr476 & Olfactory receptor 476 & -6.13 & 0.02 \\
\hline 16 & Nfam1 & NFAT activating protein with ITAM motif 1 & -6.11 & 0.02 \\
\hline 17 & Catsperg1 & Cation channel, sperm-associated auxiliary subunit gamma 1 & -6.10 & 0.02 \\
\hline 18 & $\operatorname{Prr} 30$ & Proline rich 30 & -6.07 & 0.02 \\
\hline 19 & Phgr1 & Proline/histidine/glycine-rich 1 & -5.96 & 0.20 \\
\hline 20 & Cacnalc & Calcium channel, voltage-dependent, L Type, Alpha 1C & -5.87 & 0.03 \\
\hline 21 & Olr1585 & Olfactory receptor 1585 & -5.73 & 0.03 \\
\hline 22 & Klrbla & Killer cell lectin-like receptor subfamily B member $1 \mathrm{~A}$ & -5.65 & 0.03 \\
\hline 23 & Hmgb1 & High mobility group box 1 & -5.61 & 0.41 \\
\hline 24 & Spata5 & Spermatogenesis associated 5 & -5.58 & 0.22 \\
\hline 25 & Ccdc175 & Coiled-coil domain-containing protein 175 & -5.50 & 0.03 \\
\hline 26 & Mycn & $\mathrm{V}$-myc avian myelocytomatosis viral related oncogene, neuroblastoma derived & -5.48 & 0.32 \\
\hline 27 & Gpr31 & G protein-coupled receptor 31 & -5.31 & 0.04 \\
\hline 28 & Nuak1 & NUAK family, SNF1-like kinase, 1 & -5.23 & 0.04 \\
\hline 29 & Smok2a & Sperm motility kinase $2 \mathrm{~A}$ & -5.13 & 0.04 \\
\hline 30 & Prrt2 & Proline-rich transmembrane protein 2 & -3.62 & 0.11 \\
\hline
\end{tabular}

nificant changes were observed for any treatment.

Activation of ERK1/2 and p38 MAPK by $\mathrm{Na}_{2} \mathrm{~S}_{3}$ For the next step, we decided to examine whether or not $\mathrm{Na}_{2} \mathrm{~S}_{3}$ treatment of IEC- 6 cells activated the MAPK family (Fig. 2). Activation of each MAPK was examined by immunoblotting analysis with each antibody which could detect corresponding MAPK phosphorylated at both threonine and tyrosine residues. Both ERK1 and ERK2 (ERK1/2) were robustly phosphorylated at both threonine and tyrosine residues by $100 \mu \mathrm{M} \mathrm{Na} \mathrm{S}_{3}$ at $30 \mathrm{~min}$, indicating that ERK1/2 were activated (Fig. 2A). The protein levels of ERK $1 / 2$ were not changed by $\mathrm{Na}_{2} \mathrm{~S}_{3}$. When we divided the total phosphorylation levels of ERK1/2 by the total protein levels of ERK1/2, $\mathrm{Na}_{2} \mathrm{~S}_{3}$ activated ERK1/2 1.3-, 2.6-, and 12.7-fold at 1, 10, and $100 \mu \mathrm{M}$, respectively. In contrast with ERK1/2, p38 MAPK was moderately activated by $\mathrm{Na}_{2} \mathrm{~S}_{3}$. When we divided the phosphorylation levels of p38 MAPK by the protein levels of p38 MAPK, $\mathrm{Na}_{2} \mathrm{~S}_{3}$ activated

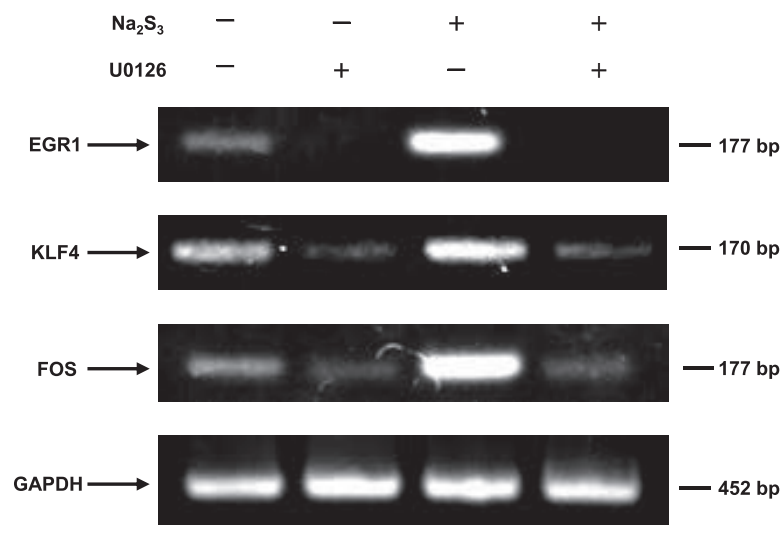

Fig. 1 Increase in the mRNA levels of EGR1, KLF4, FOS, and GAPDH after $\mathrm{Na}_{2} \mathrm{~S}_{3}$ treatment. IEC-6 cells were pretreated with or without $10 \mu \mathrm{M}$ U0126 for $30 \mathrm{~min}$ and treated with $100 \mu \mathrm{M} \mathrm{Na}_{2} \mathrm{~S}_{3}$ for $60 \mathrm{~min}$. After total RNA from IEC-6 cells was reverse transcribed, PCR was performed as described in the Materials and methods. We repeated the same experiments three times (EGR1, KLF4, and GAPDH) and six times (FOS) with reproducible results, and representative results are shown. The positions of EGR1, KLF4, FOS, and GAPDH are indicated. 
A
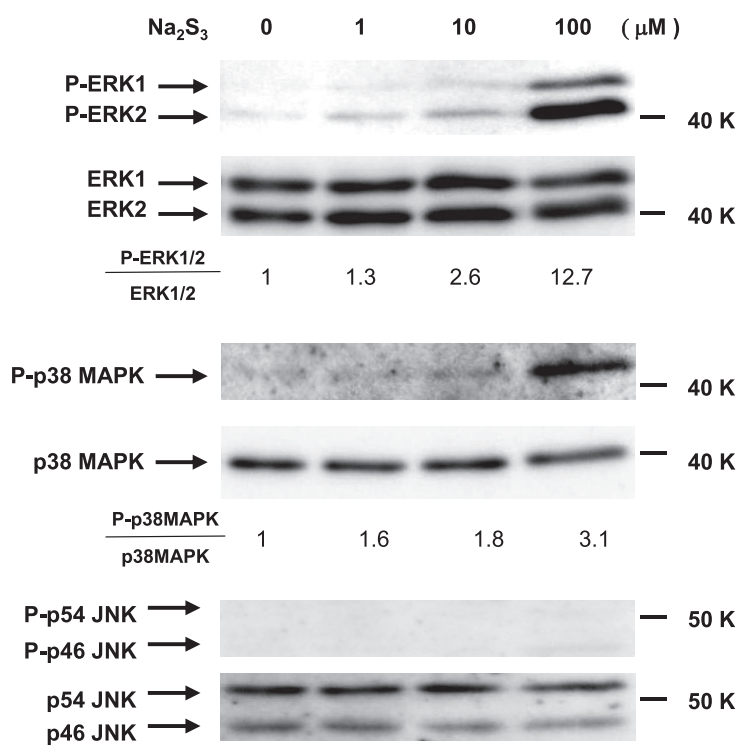

B
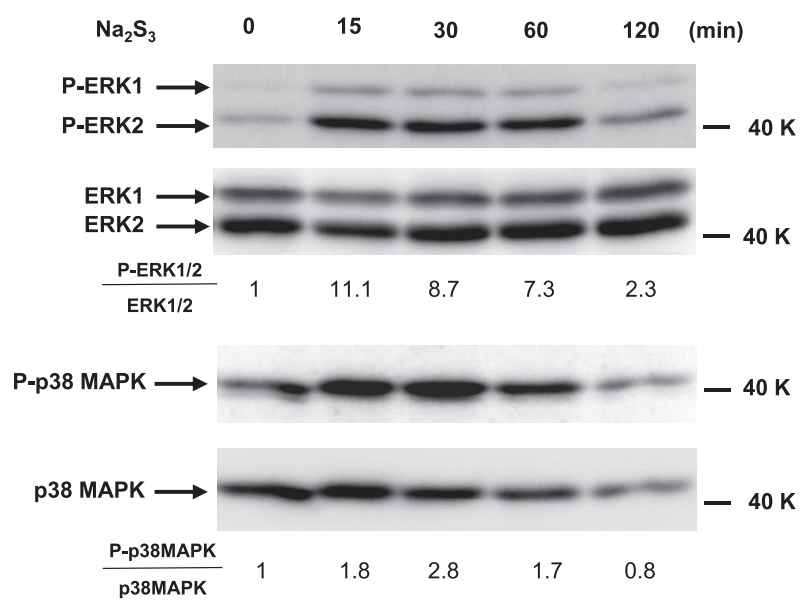

Fig. 2 Activation of ERK $1 / 2$ and p38 MAPK by Na $\mathrm{S}_{3}$. (A) IEC-6 cells were treated with $\mathrm{Na}_{2} \mathrm{~S}_{3}$ at the indicated concentrations for $30 \mathrm{~min}$. The cell extracts $(21 \mu \mathrm{g})$ were subjected to SDS-PAGE in $10 \%(\mathrm{wt} / \mathrm{vol})$ acrylamide, and an immunoblotting analysis was performed with anti-active ERK1/2 antibody (1:750), anti-phospho-p38 MAPK antibody (1:500), or anti-phospho-JNK antibody (1:750). After each antibody was stripped away, immunoblotting with an anti-ERK1/2 antibody (1:1000), anti-p38 MAPK antibody (1:500), or anti-JNK antibody (1:750), was performed. (B) IEC-6 cells were treated with $100 \mu \mathrm{M} \mathrm{Na} \mathrm{S}_{3}$ for the periods indicated. The cell extracts $(24 \mu \mathrm{g})$ were subjected to immunoblotting analysis of ERK1/2 and p38 MAPK as described above. The bands for ERK1/2 (P-ERK1/2 and ERK1/2), p38 MAPK (P-p38 MAPK and p38 MAPK), p46 JNK (P-p46 JNK and p46 JNK), and p54 JNK (P-p54 JNK and p54 JNK) are indicated. The activation levels of ERK $1 / 2$ and p38 MAPK are described as the ratio of the signal of phospho-ERK1/2 to that of ERK1/2, and the ratio of the signal of phospho-p38 MAPK to that of p38 MAPK, respectively. The ratio of the control was taken as 1, and from this value, each value was calculated. We repeated the same experiments three times (A, P-ERK1/2 and ERK1/2 in $\mathrm{B}$ ) and four times (P-p38 MAPK and p38 MAPK in B) with reproducible results, and representative results are shown.

1.6-, 1.8-, and 3.1-fold at 1,10 , and $100 \mu \mathrm{M}$, respectively, at $30 \mathrm{~min}$. We found that two types of c-jun N-terminal kinase (JNK), p54 JNK and p46 JNK, were expressed in IEC-6 cells, and that neither JNK isoform was activated at all by $\mathrm{Na}_{2} \mathrm{~S}_{3}$ treatment. The protein levels of p38 MAPK, p54 JNK, and $\mathrm{p} 46 \mathrm{JNK}$ were not changed by $\mathrm{Na}_{2} \mathrm{~S}_{3}$ treatment (Fig. 2A).

We tried to treat IEC-6 cells with $100 \mu \mathrm{M} \mathrm{Na} \mathrm{S}_{3}$ for various periods (Fig. 2B). The activation of ERK1/2 was observed from $15 \mathrm{~min}$ after the start of $\mathrm{Na}_{2} \mathrm{~S}_{3}$ treatment, and it was decreased at $120 \mathrm{~min}$. $\mathrm{Na}_{2} \mathrm{~S}_{3}$ activated ERK1/2 11.1-, 8.7-, 7.3-, and 2.3fold at 15, 30, 60, and $120 \mathrm{~min}$. The activation levels of p38 MAPK were lower than that of ERK1/2 at any time point, and $\mathrm{Na}_{2} \mathrm{~S}_{3}$ activated p38 MAPK 1.8-, 2.8-, 1.7-fold at 15, 30, and $60 \mathrm{~min}$. The protein levels of ERK1/2 and p38 MAPK were not changed by $\mathrm{Na}_{2} \mathrm{~S}_{3}$ treatment, except that the protein level of p38 MAPK was decreased at $120 \mathrm{~min}$ by an unknown mechanism.
Involvement of MEK1/2 and Raf in the $\mathrm{Na}_{2} \mathrm{~S}_{3}$-induced activation of ERK1/2

Because ERK1/2 were strongly activated by $\mathrm{Na}_{2} \mathrm{~S}_{3}$, we next examined the signal transduction mechanisms by which $\mathrm{Na}_{2} \mathrm{~S}_{3}$ activated ERK1/2 (Fig. 3). We noticed that ERK1/2 were slightly activated in the absence of $\mathrm{Na}_{2} \mathrm{~S}_{3}$, and U0126, an inhibitor of MEK1/2, inhibited this basal activation of ERK1/2 completely (Fig. 3A). $\mathrm{Na}_{2} \mathrm{~S}_{3}$ activated ERK1/2 more than 10-fold, and U0126 inhibited the activation almost completely.

We examined the possible involvement of Raf in the $\mathrm{Na}_{2} \mathrm{~S}_{3}$-induced activation of ERK1/2 (Fig. 3B). In this experiment, ERK1/2 were activated approximately 4.7-fold, and BAY43-9006, an inhibitor of Raf-1 and B-Raf, inhibited the activation. In contrast with U0126, we noted that BAY43-9006 did not inhibit the basal activation of ERK1/2 in the absence of $\mathrm{Na}_{2} \mathrm{~S}_{3}$. These results suggested that Raf-1 or B-Raf was involved in the activation of ERK1/2 by $\mathrm{Na}_{2} \mathrm{~S}_{3}$, but not under the basal conditions. The protein levels of ERK1/2 were not changed by any 
A

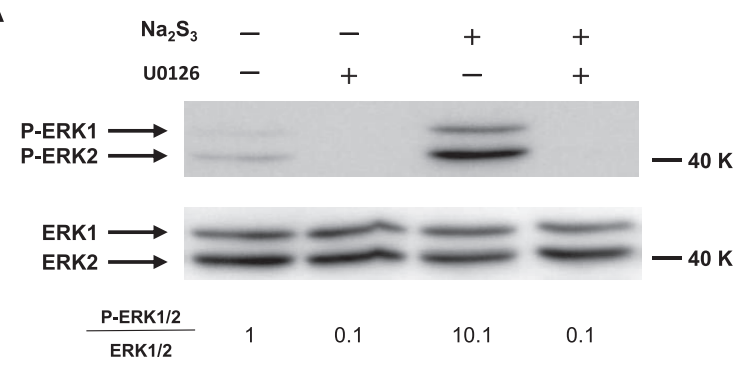

B

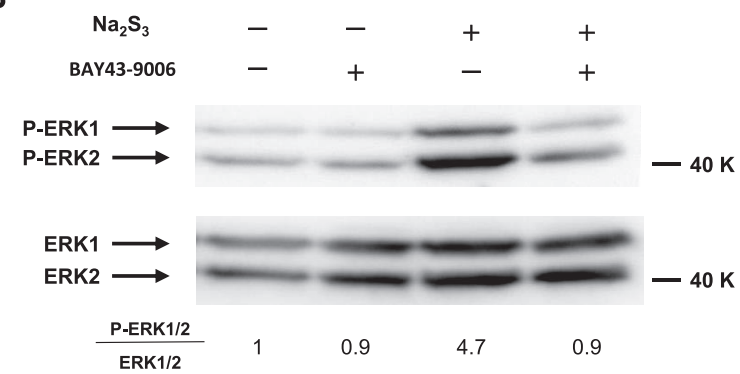

Fig. 3 Involvement of MEK $1 / 2$ and Raf-1/B-Raf in the $\mathrm{Na}_{2} \mathrm{~S}_{3}$-induced activation of ERK1/2. IEC-6 cells were pretreated with $10 \mu \mathrm{M}$ U0126 (A) or $10 \mu \mathrm{M}$ BAY43-9006 (B), for $30 \mathrm{~min}$, and treated with $100 \mu \mathrm{M} \mathrm{Na}_{2} \mathrm{~S}_{3}$ for $30 \mathrm{~min}$. The cell extracts $(39 \mu \mathrm{g}$ in $\mathrm{A}, 43 \mu \mathrm{g}$ in $\mathrm{B})$ were subjected to immunoblotting analysis of ERK $1 / 2$ as described in the legend to Fig. 1. The bands for ERK1/2 (P-ERK1/2 and ERK1/2) are indicated. The activation level of ERK $1 / 2$ is described as the ratio of the signal of phospho-ERK $1 / 2$ to that of ERK1/2, as described in the legend to Fig. 1. We repeated the same experiments three times with reproducible results, and representative results are shown.

treatment (Fig. 3A and B).

\section{Activation and Gel-shift of ERK5 after $\mathrm{Na}_{2} \mathrm{~S}_{3}$ treat- ment}

We next examined the activation of ERK5. The available antibody that was specific to ERK5 phosphorylated at both threonine 219 (Thr219) and Tyr221 (anti-phospho-ERK5 antibody) did not detect ERK5 after $\mathrm{Na}_{2} \mathrm{~S}_{3}$ treatment (Fig. 4A). However, when we used an anti-ERK5 antibody, which was produced by immunizing rabbits using a synthetic peptide corresponding to residues surrounding Leu556 of human ERK5, the electrophoretic mobility of ERK5 decreased after treatment of the cells with $\mathrm{Na}_{2} \mathrm{~S}_{3}$. When we divided the signal of shifted-bands by that of total ERK5 to determine the gel-shift ratio, it was increased from 0.2 to 0.6 by $100 \mu \mathrm{M} \mathrm{Na} \mathrm{S}_{3}$. It was reported that autophosphorylation by activated ERK5 in the C-terminal region induced a gel-shift of ERK5 (Morimoto et al. 2007). Therefore, we decided to re-examine the activation of ERK5 by $\mathrm{Na}_{2} \mathrm{~S}_{3}$. ERK5 was activated by dual phosphorylation of Thr-Glu-Tyr region (for review, see Kamakura et al. 1999). Because ERK1/2 were activated also by dual phosphorylation of Thr-GluTyr region, we considered the possibility that anti-active ERK1/2 antibody might cross-react with activated ERK5. Therefore, we did the immunoblotting analysis of active ERK5 using anti-active ERK1/2 antibody (Fig. 4B). We found an immunoreactive band at the position of ERK5, and the immunoreactivity was augmented by $\mathrm{Na}_{2} \mathrm{~S}_{3}$ treatment. When we divided the signal of phosphorylation of ERK5 by that of total ERK5, the activation of ERK5 was increased to 1.4-fold. These results clearly indicated that $\mathrm{Na}_{2} \mathrm{~S}_{3}$ activated ERK5. In addition, the augmentation was inhibited in the presence of U0126. Because U0126 has been reported to inhibit MEK5 as well as MEK1/2 (Kamakura et al. 1999), these results suggested that ERK5 was activated by MEK 5 after $\mathrm{Na}_{2} \mathrm{~S}_{3}$ treatment. We confirmed that ERK1/2 was activated by $\mathrm{Na}_{2} \mathrm{~S}_{3}$, and the activation was inhibited in the presence of U0126 on the same membrane (Fig. 4B).

\section{Molecular mechanisms for the Gel-shift of ERK5 af-} ter $\mathrm{Na}_{2} \mathrm{~S}_{3}$ treatment

Because $\mathrm{Na}_{2} \mathrm{~S}_{3}$ activated ERK5, we wanted to confirm that the gel-shift of ERK5 was due to the autophosphorylation by activated ERK5. It has been reported that MEK5 was activated by B-Raf (Tusa et al. 2018); therefore, we examined whether or not the gel shift of ERK5 was inhibited by BAY43-9006 (Fig. 4C). In this experiment, the gel-shift ratio of ERK5 was increased to 0.4 from 0.2 after $\mathrm{Na}_{2} \mathrm{~S}_{3}$ treatment. It was interesting that the gel-shift was decreased to 0.2 in the presence of BAY43-9006 and $\mathrm{Na}_{2} \mathrm{~S}_{3}$. These results suggested that B-Raf was involved in the gel-shift of ERK5 by $\mathrm{Na}_{2} \mathrm{~S}_{3}$.

We next examined whether or not the gel-shift of ERK5 was due to phosphorylation. For this purpose, we treated the cells with $\mathrm{Na}_{2} \mathrm{~S}_{3}$ and U0126, and performed Phos-tag SDS-PAGE, in addition to standard SDS-PAGE (Fig. 4D). Phos-tag binds specifically to the phosphate group (Kinoshita et al. 2009). Therefore, Phos-tag traps phosphorylated proteins during SDS-PAGE, allowing detection of phosphorylated and non-phosphorylated proteins as different bands (Kinoshita et al. 2009; Kimura et al. 2016). When we used the standard gel, the gel-shift ratio of ERK5 was increased to 0.4 from 0.3 after $\mathrm{Na}_{2} \mathrm{~S}_{3}$ treatment, and U0126 decreased the gel-shift ratio to 0.3. In the case of the Phos-tag gel, the gel-shift of ERK5 was more clearly observed than the standard gel, 

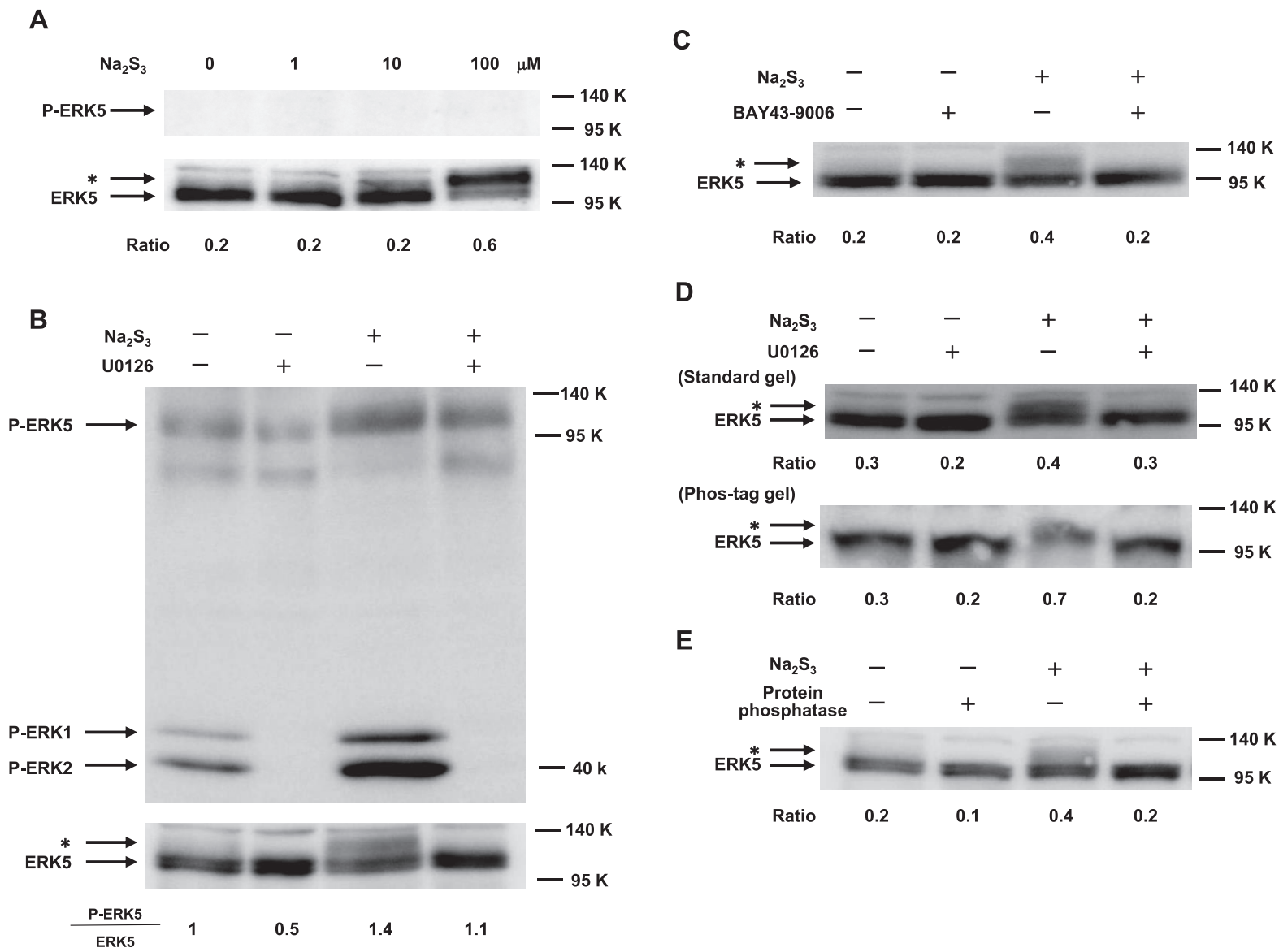

Fig. 4 Activation and gel-shift of ERK5 through phosphorylation in response to $\mathrm{Na}_{2} \mathrm{~S}_{3}$. (A) IEC-6 cells were treated with $\mathrm{Na}_{2} \mathrm{~S}_{3}$ at the indicated concentrations for $30 \mathrm{~min}$. The cell extracts $(21 \mu \mathrm{g})$ were subjected to SDS-PAGE in $7.5 \%$ (wt/vol) acrylamide, and immunoblotting analysis was performed with an anti-phospho ERK5 antibody (1:750). After the antibody was stripped away, immunoblotting with an anti-ERK5 antibody (1:1000) was performed. (B) IEC-6 cells were pretreated with $10 \mu \mathrm{M}$ U0126 for $30 \mathrm{~min}$, and treated with $100 \mu \mathrm{M} \mathrm{Na} \mathrm{S}_{3}$ for $30 \mathrm{~min}$. The cell extracts $(39 \mu \mathrm{g})$ were subjected to SDSPAGE followed by immunoblotting analysis with anti-active ERK1/2 antibody (1:750). After the antibody was stripped away, immunoblotting with an anti-ERK5 antibody (1:1000) was performed. (C) IEC-6 cells were pretreated with $10 \mu \mathrm{M}$ BAY43-9006 for $30 \mathrm{~min}$, and treated with $100 \mu \mathrm{M} \mathrm{Na} \mathrm{S}_{3}$ for $30 \mathrm{~min}$. The cell extracts $(43 \mu \mathrm{g})$ were subjected to immunoblotting analysis of ERK5 as described above. (D) IEC-6 cells were pretreated with $10 \mu \mathrm{M}$ U0126 for 30 min, and treated with $100 \mu \mathrm{M} \mathrm{Na}_{2} \mathrm{~S}_{3}$ for $30 \mathrm{~min}$. The cell extracts $(39 \mu \mathrm{g})$ were subjected to standard SDS-PAGE (Standard gel) or PhosTag-SDS-PAGE (Phos-tag gel), followed by immunoblotting analysis of ERK5. (E) IEC-6 cells were treated with $100 \mu \mathrm{M}$ $\mathrm{Na}_{2} \mathrm{~S}_{3}$ for $30 \mathrm{~min}$, and the cell extracts were prepared as described in the Materials and methods. The cell extract $(40 \mu \mathrm{g})$ was incubated with or without 400 Units of $\lambda$-protein phosphatase at $30^{\circ} \mathrm{C}$ for $30 \mathrm{~min}$, followed by SDS treatment. The samples $(10 \mu \mathrm{g})$ were subjected to immunoblotting analysis of ERK5. The bands for ERK5 (P-ERK5 and ERK5) and ERK1/2 (P-ERK1/2 and ERK1/2) are indicated. The gel-shifted ERK5 is indicated by asterisks. The ratio of the gel-shift of ERK5 (Ratio) was calculated as described in the Materials and methods, and is indicated (A, C, D, and E). The activation level of ERK5 is described as the ratio of the signal of phospho-ERK5 to that of ERK5 (B). We repeated the same experiments three times $(A, B, C$, and $D)$ and four times $(E)$ with reproducible results, and representative results are shown.

and the gel-shift ratio was increased from 0.3 to 0.7 after $\mathrm{Na}_{2} \mathrm{~S}_{3}$ treatment. We confirmed that the gelshift of ERK5 was decreased to the control level by U0126.

In order to further confirm the involvement of phosphorylation in the gel-shift of ERK5, we incubated the cell extract with $\lambda$-protein phosphatase in vitro. The gel-shift ratio was increased from 0.2 to
0.4 by $\mathrm{Na}_{2} \mathrm{~S}_{3}$ treatment (Fig. $4 \mathrm{E}$ ). We found that the gel-shift ratio returned to 0.2 after treatment with $\lambda$-protein phosphatase in vitro (Fig. $4 \mathrm{E}$ ). These results further supported the idea that the gel-shift of ERK5 was due to phosphorylation.

Necessity of ERK5 activity for the gel-shift of ERK5 We finally examined the effects of ERK5-IN-1, an 
A

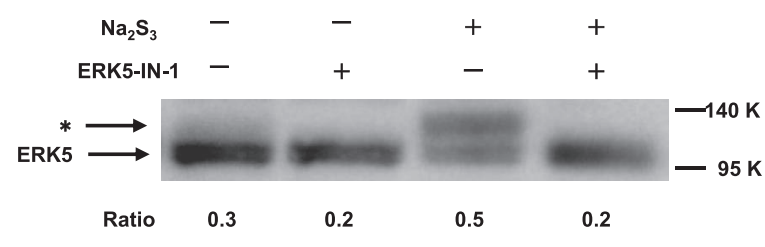

B

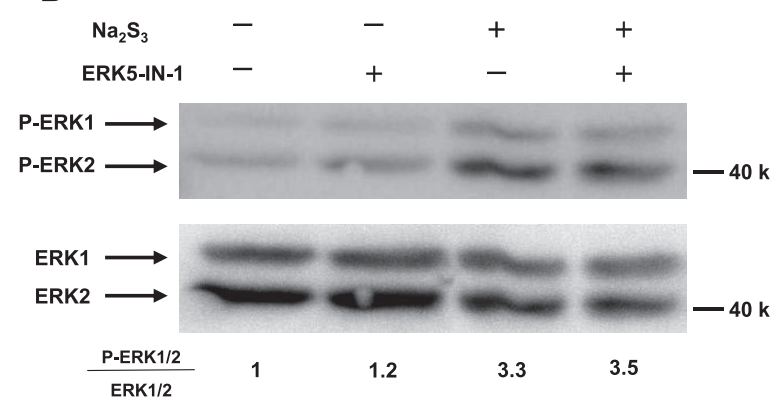

Fig. 5 Necessity for the activity of ERK5 in the $\mathrm{Na}_{2} \mathrm{~S}_{3}$-induced gel-shift of ERK5. IEC-6 cells were pretreated with $1 \mu \mathrm{M}$ of ERK5-IN-1 for $30 \mathrm{~min}$, and treated with $100 \mu \mathrm{M}$ $\mathrm{Na}_{2} \mathrm{~S}_{3}$ for $30 \mathrm{~min}$. The cell extracts $(28 \mu \mathrm{g})$ were subjected to immunoblotting analysis of ERK5 (A) and ERK1/2 (B) as described in the legends to Fig. 4 and Fig. 1, respectively. The bands for ERK5 and ERK1/2 (P-ERK1/2 and ERK1/2) are indicated. The gel-shifted ERK5 is indicated by an asterisk. The ratio of the gel-shift of ERK5 (Ratio) is indicated (A). The activation level of ERK $1 / 2$ is described as the ratio of the signal of phospho-ERK1/2 to that of ERK $1 / 2$ (B). We repeated the same experiments three times with reproducible results, and representative results are shown.

ATP-competitive inhibitor of ERK5, on the $\mathrm{Na}_{2} \mathrm{~S}_{3}$ induced gel-shift (Fig. 5A). In this experiment, the gel-shift ratio of ERK5 was 0.3 in the absence of $\mathrm{Na}_{2} \mathrm{~S}_{3}$, and $\mathrm{Na}_{2} \mathrm{~S}_{3}$ enhanced the gel-shift ratio to 0.5 . The gel-shift of ERK5 in the presence and absence of $\mathrm{Na}_{2} \mathrm{~S}_{3}$ was strongly inhibited by ERK5-IN-1. We confirmed that ERK5-IN-1 did not inhibit the ERK1/2 activation by $\mathrm{Na}_{2} \mathrm{~S}_{3}$ (Fig. 5B). The protein levels of ERK1/2 were not affected by any treatment (Fig. 5B). These results clearly indicated that ERK5-IN-1 had no effects on the $\mathrm{Na}_{2} \mathrm{~S}_{3}$-induced activation of ERK1/2. From these results, we concluded that the gel-shift of ERK5 was due to the autophosphorylation by activated ERK5.

\section{DISCUSSION}

There are many reports indicating that $\mathrm{H}_{2} \mathrm{~S}$ is produced by the intestinal microbiota as well as in the intestinal epithelial cells (Blachier et al. 2019). Therefore, it is highly possible that the intestinal epithelial cells are exposed to the higher concentration of $\mathrm{H}_{2} \mathrm{~S}$, compared with any other cells in other organs (Rose et al. 2005). It has become apparent that $\mathrm{H}_{2} \mathrm{~S}$ is converted to $\mathrm{H}_{2} \mathrm{~S}_{\mathrm{n}}$, and many of the effects of $\mathrm{H}_{2} \mathrm{~S}$ are conducted by $\mathrm{H}_{2} \mathrm{~S}_{\mathrm{n}}$ (Kimura 2017). In the present study, we sought to examine the effects of $\mathrm{H}_{2} \mathrm{~S}_{\mathrm{n}}$ on the functions of intestinal epithelial cells. For this purpose, we treated IEC- 6 cells, a cultured intestinal epithelial cell line, with $\mathrm{Na}_{2} \mathrm{~S}_{3}$ that releases $\mathrm{H}_{2} \mathrm{~S}_{\mathrm{n}}$. We first examined the effects of $\mathrm{Na}_{2} \mathrm{~S}_{3}$ on the gene expression. We have been studying the physiological and pathophysiological roles of the MAP kinase pathways in the cell functions, such as desensitization of epidermal growth factor receptor family and cell migration (Higa-Nakamine et al. 2012; Nishi et al. 2015; Kondo et al. 2016). Therefore, we focused on the expression of the genes that are regulated by the MAP kinase pathways.

It is well-known that the gene expression of EGR1 and FOS is regulated by the ERK1/2 pathways. Our DNA microarray analysis and RT-PCR revealed that the mRNAs of EGR1 and FOS were increased by $\mathrm{Na}_{2} \mathrm{~S}_{3}$ treatment. The increases in these mRNAs were inhibited by U0126, indicating that the ERK1/2 pathway was involved in the gene expression. And then, we confirmed that the treatment of IEC- 6 cells with $\mathrm{Na}_{2} \mathrm{~S}_{3}$ activated ERK1/2. In addition, we found that the mRNA of KLF4 was increased also after $\mathrm{Na}_{2} \mathrm{~S}_{3}$ treatment, and U0126 inhibited the effect of $\mathrm{Na}_{2} \mathrm{~S}_{3}$. Because the MAP kinase pathway that was involved in KLF4 gene expression was reported to be the ERK5 pathway (Ohnesorge et al. 2010), and U0126 inhibited reportedly the activation of ERK5 as well as ERK1/2 (Kamakura et al. 1999), we decided to examine the activation of ERK5 by $\mathrm{Na}_{2} \mathrm{~S}_{3}$. Unexpectedly, we could not detect the activation of ERK5 with anti-phospho-ERK5 antibody after $\mathrm{Na}_{2} \mathrm{~S}_{3}$ treatment. However, using antiactive ERK1/2 antibody, we could obtain the clear results indicating that $\mathrm{Na}_{2} \mathrm{~S}_{3}$ activated ERK5 and that U0126 inhibited the activation. The reasons why anti-phospho-ERK5 antibody did not detect the activated ERK5 are not clear at present. From the instruction manual of anti-phospho-ERK5 antibody, the sensitivity of the antibody might not be high enough to detect endogenous ERK5 in IEC-6 cells. To our knowledge, this is the first report about the activation by $\mathrm{Na}_{2} \mathrm{~S}_{3}$ of ERK1/2 and ERK5 in any cell systems.

The molecular mechanisms by which $\mathrm{Na}_{2} \mathrm{~S}_{3}$ activated ERK1/2 and ERK5 are not clear at present. Inhibitory effects of BAY43-9006 on ERK1/2 activation indicated that Raf-1 or B-Raf was involved in the activation of ERK1/2. It is well-known that 


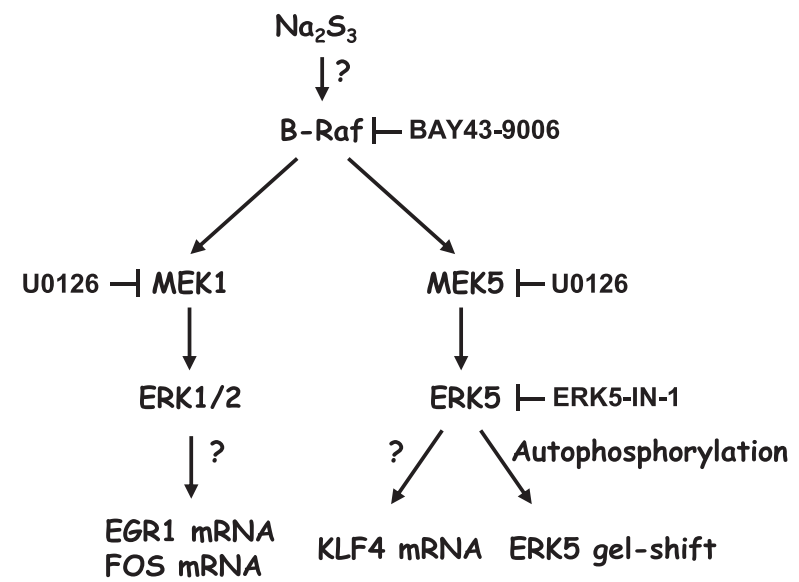

Fig. 6 Effects of $\mathrm{Na}_{2} \mathrm{~S}_{3}$ on the pathways of ERK1/2 and ERK5. $\mathrm{Na}_{2} \mathrm{~S}_{3}$ may activate the ERK1/2 and ERK5 pathways by activation of $B-$ Raf. It has been reported that ERK $1 / 2$ and ERK5 induced the gene expression of EGR1, FOS, and KLF4, respectively. Autophosphorylation of ERK5 induces the gel-shift.

Raf-1 is activated by Ras or protein kinase C. However, the inhibitors of Ras or protein kinase $\mathrm{C}$ that we tested did not inhibit the $\mathrm{Na}_{2} \mathrm{~S}_{3}$-induced activation of ERK1/2 (K. Arakaki and H. Yamamoto, unpublished observation). It has been reported that B-Raf activated both MEK1/2 and MEK5 (for review, see Tusa et al. 2018). Taken together, $\mathrm{Na}_{2} \mathrm{~S}_{3}$ may activate B-Raf directly, followed by the activation of both the MEK1/2-ERK1/2 and MEK5-ERK5 pathways (Fig. 6). Possible involvement of B-Raf in the effects of $\mathrm{Na}_{2} \mathrm{~S}_{3}$ is worth examining in a future study.

It has been reported that activation of the ERK5KLF4 pathway inhibited the migration of endothelial cells (Spiering et al. 2009; Komaravolu et al. 2015). In the preliminary experiments, $\mathrm{Na}_{2} \mathrm{~S}_{3}$ inhibited the cell migration of IEC- 6 cells (our unpublished observation). However, the effects of U0126 and ERK5-IN-1 on the cell migration were not clear. It was also reported that the ERK5/KLF4 pathway was involved in the cell proliferation and differentiation. Therefore, the outcomes of the activation of the ERK1/2 and ERK5 pathway should be examined precisely in future studies. These studies are crucial for the understanding of the roles of $\mathrm{H}_{2} \mathrm{~S}_{\mathrm{n}}$ in the regulation of the functions of intestinal epithelial cells.

In the present study, we could obtain the clear effects of $\mathrm{Na}_{2} \mathrm{~S}_{3}$ on the ERK1/2 and ERK5 pathways at $0.1 \mathrm{mM}$. It is not clear at present whether or not intestinal epithelial cells are exposed to $0.1 \mathrm{mM}$ $\mathrm{H}_{2} \mathrm{~S}_{\mathrm{n}}$ in vivo. However, it was reported that the con- centration of $\mathrm{H}_{2} \mathrm{~S}$ ranged from $0.2 \mathrm{mM}$ to $1 \mathrm{mM}$ in mouse stools and might reach $3.4 \mathrm{mM}$ in human stools (Rose et al. 2005). Therefore, the concentration of $\mathrm{H}_{2} \mathrm{~S}_{\mathrm{n}}$ may become higher than $0.1 \mathrm{mM}$ under the normal conditions. In addition, there are many reports about the involvement of $\mathrm{H}_{2} \mathrm{~S}$ in IBD and colorectal cancer (Wallace et al. 2007; Hirata et al. 2011; Guo et al. 2016). When the protective effects of mucus against the high concentration of $\mathrm{H}_{2} \mathrm{~S}_{\mathrm{n}}$ were affected in the inflammatory conditions, intestinal epithelial cells may be exposed directly to the higher concentration of $\mathrm{H}_{2} \mathrm{~S}_{\mathrm{n}}$ than $0.1 \mathrm{mM}$. In conclusion, the present study contributes to the understanding of the physiological and pathophysiological roles of $\mathrm{H}_{2} \mathrm{~S}_{\mathrm{n}}$ in the functions of gastrointestinal tract and the development of novel therapies of IBD and colorectal cancer.

\section{Acknowledgements}

This work was supported by JSPS KAKENHI Grant Numbers 16K07058 and 17K07112. We thank the Research Laboratory Center of Faculty of Medicine, University of the Ryukyus for technical support.

\section{CONFLICTS OF INTEREST}

The authors declare that no significant conflicts of interest exist with any companies/organizations whose products or services may be discussed in this article.

\section{REFERENCES}

Blachier F, Beaumont M and Kim E (2019) Cysteine-derived hydrogen sulfide and gut health: a matter of endogenous or bacterial origin. Curr Opin Clin Nutr Metab Care 22, 6875.

Guo F-F, Yu T-C, Hong J and Fang J-Y (2016) Emerging roles of hydrogen sulfide in inflammatory and neoplastic colonic diseases. Front Physiol 7, 156.

Higa-Nakamine S, Maeda N, Toku S, Yamamoto T, Yingyuenyong $\mathrm{M}$ et al. (2012) Selective cleavage of ErbB4 by G-protein-coupled gonadotropin-releasing hormone receptor in cultured hypothalamic neurons. J Cell Physiol 227, 24922501.

Hirata I, Naito Y, Takagi T, Mizushima K, Suzuki T et al. (2011) Endogenous hydrogen sulfide is an anti-inflammatory molecule in dextran sodium sulfate-induced colitis in mice. Dig Dis Sci 56, 1379-1386.

Hosoki R, Matsuki N and Kimura H (1997) The possible role of hydrogen sulfide as an endogenous smooth muscle relaxant in synergy with nitric oxide. Biochem Biophys Res Commun 237, 527-531.

Hu LF, Lu M, Wu ZY, Wong PT and Bian JS (2009) Hydrogen sulfide inhibits rotenone-induced apoptosis via preservation of mitochondrial function. Mol Pharmacol 75, 27-34. 
Huang da W, Sherman BT and Lempicki RA (2009) Systematic and integrative analysis of large gene lists using DAVID bioinformatics resources. Nat Protoc 4, 44-57.

Kakinohana M, Marutani E, Tokuda K, Kida K, Kosugi S et al. (2019) Breathing hydrogen sulfide prevents delayed paraplegia in mice. Free Radic Biol Med 131, 243-250.

Kamakura S, Moriguchi T and Nishida E (1999) Activation of the protein kinase ERK5/BMK1 by receptor tyrosine kinases. Identification and characterization of a signaling pathway to the nucleus. J Biol Chem 274, 26563-26571.

Kimura H (2017) Hydrogen sulfide and polysulfide signaling. Antioxid Redox Signal 27, 619-621.

Kimura T, Hatsuta H, Masuda-Suzukake M, Hosokawa M, Ishiguro K et al. (2016) The abundance of nonphosphorylated tau in mouse and human tauopathy brains revealed by the use of Phos-tag method. Am J Pathol 186, 398-409.

Kinoshita E, Kinoshita-Kikuta E and Koike T (2009) Separation and detection of large phosphoproteins using Phos-tag SDSPAGE. Nat Protoc 4, 1513-1521.

Kondo Y, Higa-Nakamine S, Maeda N, Toku S, Kakinohana M et al. (2016) Stimulation of cell migration by flagellin through the p38 MAP kinase pathway in cultured intestinal epithelial cells. $J$ Cell Biochem 117, 247-258.

Komaravolu RK, Adam C, Moonen J-R AJ, Harmsen MC, Goebeler M et al. (2015) Erk5 inhibits endothelial migration via KLF2-dependent down-regulation of PAK1. Cardiovasc Res 105, 86-95.

Laemmli UK (1970) Cleavage of structural proteins during the assembly of the head of bacteriophage T4. Nature 227, 680 685.

Miyamoto R, Koike S, Takano Y, Shibuya N, Kimura Y et al. (2017) Polysulfides $\left(\mathrm{H}_{2} \mathrm{~S}_{\mathrm{n}}\right)$ produced from the interaction of hydrogen sulfide $\left(\mathrm{H}_{2} \mathrm{~S}\right)$ and nitric oxide (NO) activate TRPA1 channels. Sci Rep 7, 45995.

Mizutani A, Maeda N, Toku S, Higa-Nakamine S, Isohama Y et al. (2011) Interaction of ethyl pyruvate in vitro with NF- $\mathrm{KB}$ subunits, RelA and p50. Eur J Pharmacol 650, 151-156.

Morimoto H, Kondoh K, Nishimoto S, Terasawa K and Nishida E (2007) Activation of a C-terminal transcriptional activation domain of ERK5 by autophosphorylation. J Biol Chem
282, 35449-35456.

Nishi $\mathrm{H}$, Maeda N, Izumi S, Higa-Nakamine S, Toku S et al. (2015) Differential regulation of epidermal growth factor receptor by hydrogen peroxide and flagellin in cultured lung alveolar epithelial cells. Eur J Pharmacol 748, 133-142.

Noguchi N, Kondo Y, Maeda N, Higa-Nakamine S, Toku S et al. (2013) Phosphorylation of epidermal growth factor receptor at serine 1047 by MAP kinase-activated protein kinase- 2 in cultured lung epithelial cells treated with flagellin. Arch Biochem Biophys 529, 75-85.

Ohnesorge N, Viemann D, Schmidt N, Czymai T, Spiering D et al. (2010) ERK5 activation elicits a vasoprotective endothelial phenotype via induction of Kruppel-like factor 4 (KLF4). $J$ Biol Chem 285, 26199-26210.

Rose P, Moore PK, Ming SH, Nam OC, Armstrong JS et al. (2005) Hydrogen sulfide protects colon cancer cells from chemopreventative agent beta-phenylethyl isothiocyanate induced apotosis. World J Gastroenterol 11, 3990-3997.

Rowan FE, Docherty NG, Coffey JC and O'Connell PR (2009) Sulphate-reducing bacteria and hydrogen sulphide in the aetiology of ulcerative colitis. Br J Surg 96, 151-158.

Spiering D, Schmolke M, Ohnesorge N, Schmidt M, Goebeler M et al. (2009) MEK5/ERK5 signaling modulates endothelial cell migration and focal contact turnover. $J$ Biol Chem 284, 24972-24980.

Towbin H, Staehelin T and Gordon J (1979) Electrophoretic transfer of proteins from polyacrylamide gels to nitrocellulose sheets: procedure and some applications. Proc Natl Acad Sci USA 76, 4350-4354.

Tusa I, Gagliardi S, Tubita A, Pandolfi S, Urso C et al. (2018) ERK5 is activated by oncogenic BRAF and promotes melanoma growth. Oncogene 37, 2601-2614.

Wallace JL, Dcay M, McKnight W and Martin GR (2007) Hydrogen sulfide enhances ulcer healing in rats. FASEB J 21, 4070-4076.

Xie H, Xu Q, Jia J, Ao G, Sun Y et al. (2015) Hydrogen sulfide protects against myocardial ischemia and reperfusion injury by activating AMP-activated protein kinase to restore autophagic flux. Biochem Biophys Res Commun 458, 632-638. 